\title{
Prevalence of asymptomatic bacteriuria in students of University of Port Harcourt Demonstration Secondary School.
}

\author{
*FRANK-PETERSIDE, N.; WOKOMA, E.C. \\ Department of Microbiology, Faculty of Science, University of Port Harcourt. \\ PMB 5323. Choba, Rivers State. Nigeria. E-mail address nnefp@yahoo.co.uk, (*corresponding author).
}

\begin{abstract}
This study was carried out to determine the prevalence of asymptomatic bacteriuria among the students of University of Port Harcourt Demonstration, Secondary School. Urine samples were collected from 50 males and 50 females. The samples were cultured on CLED and MacConkey agar. Growth was observed in 89 (89\%) of the samples while there was no growth in $11(11 \%)$ of the samples. Of the 89 samples with growth 59 (66\%) had no significant bacteriuria, $10(11 \%)$ had significant growth and $20(22 \%)$ had mixed culture growth. Prevalence of significant asymptomatic bacteriuria was higher in females $6(60 \%)$ than males $4(40 \%)$. The organisms isolated were S. aureus; S. epidermidis; E. coli; Pseudomonas spp and Proteus spp. The antibiotic sensitivity of the isolates was also determined. @ JASEM
\end{abstract}

Asymptomatic bacteriuria (ABU) is defined as significant bacterial count in the urine, usually $10^{5}$ cfu per $\mathrm{ml}$ in an individual without symptoms of urinary tract infections (UTI) [Smith, 1994]. Stamm and Hooton, 1993 referred to UTI as a clinical (symptomatic) or subclinical (asymptomatic) disease that may involve just the lower tract or both the lower and upper tracts - infection may involve single sites such as urethra - urethritis, prostrate-prostitis, bladder, cystitis, kidney - pyelonephritis but the whole system is always at a risk of invasion by bacteria once any part is infected (Atlas, 1986). Recurrence of UTI may be caused by a relapse or reinfection. Persistence of UTI, associated with the same organism for a long time indicates the presence of chronic infection. Urine culture is the gold standard for UTI because when bacteria are deposited in the urine, they tend to increase greatly (Nester et al, 1998). A method which distinguishes contamination from infection is required and the most suitable sample is the early morning urine (Bailey and Scott 1994). UTI affects all age groups from neonates to geriatrics. Some of the factors contributing to UTI include sex and age, pregnancy, obstruction of urinary flow and underlying diseases (Prescott, 1999; Ojiegbe \& Nworie, 2000; Siegel et al, 1980; Black, 1993; Hugo \& Russell, 1992; Epoke et al, 2000; Guyton and Hall, 2000, and Bailey and Scott, 1994). Due to the relative predictability of uropathogens, and time and delay associated with urine culture results, antibiotic treatment for UTI relies heavily on empiric theory. The frequency with which different species that cause UTI have been isolated from urine, varies depending on the particular clinical problem under study; the patient population, the bacteriologic technique and the interpretation of results. This study is aimed at ascertaining the prevalence of $\mathrm{ABU}$ in students of University of Port - Harcourt Demonstration
Secondary School (UDSS), Port Harcourt. The organisms isolated will be characterized and antibiotic sensitivity, determined.

\section{MATERIALS AND METHODS}

One hundred UDSS students within the age range of 10 to 17 years were sampled for asymptomatic bacteriuria. Fifty (50) were boys and fifty girls. Prior to sample collection, questionnaires were given to the students. The first part contained the Biodata of the students e.g. name, sex, age, parents occupation, number of brothers and sisters as well as history of UTI. Students on medication were excluded from this study. The participating students were instructed to wash their external genital with mild toilet soap and rinse thoroughly with clean water. Thereafter, midstream urine was to be collected into the sterile specimen bottles, provided. The samples were labeled against the name of student in accordance with the supplied biodata. Prior to culturing, samples were preserved in the refrigerator but were eventually cultured within $2 \mathrm{hrs}$ of collection. The samples were examined macrospically. The samples were cultured on MacConkey and CLED agar and characterized biochemically as described by Cheesebrough.2000. For antibiotic sensitivity, a standard wire loop (3mm diameter) was used to collect a portion of the bacteria colony. This was streaked in a plate of nutrient agar. The sensitivity disc (multo-disk) was then placed on the streaked nutrient agar and incubated at $37^{\circ} \mathrm{C}$ for 24hrs. Thereafter, the degree of sensitivity was determined by measuring the visible zones of inhibition. Zone of inhibition $<3 \mathrm{~mm}$ in diameter indicates resistance and zone of inhibition $>3 \mathrm{~mm}$ in diameter indicates susceptibility of the organism (Gill, 1990). The antibiotics used for sensitivity study are as follows OFX - Tarivia; NA - Nalidixic Acid, PEF- peflacine, CN-Gentamycin, Au-Augumentin, CPX- Ciproflox, SXT- Septrin, CEP - Ceporek, S- 
Streptomycin, PN - Ampicillin, , E - Erytromycine, LC - Lincocin, APX - Ampiclox, RD -Rifampin, FLX - Floxapen, NB - Norfloxacin and CH Chloramphenicol.

\section{RESULTS}

Urine samples from one hundred (100) UDSS students within the age range of 10 to 17 years were collected and examined for the presence of bacteria using a semi quantitative method. The results obtained are presented below. The incidence of significant bacteriuria in the population examined is reported in Table 1. Ten participants had significant bacteruria, six females and four males (Table 1).
Table 2 reports the summary of the occurrence of the bacterial isolates. Of the ten organisms isolated, 3 were S. aureus, 3 S.epidermidis, 2 E. coli, 1 Pseudomonas spp and 1 Proteus spp (Table 2).

Table 3 reports the antibiotic susceptibility pattern of the gram negative isolates. All the organisms were resistant to Tarivia, peflacine, Gentamycin, and ciproflex. Some of the organisms were resistant and others susceptible to the other antibiotics (Table 3)

Table 4 is the antibiotic susceptibility pattern of the gram positive isolates. All the organisms were susceptible to Lincocin, Gentamycin, Ampiclox, Rifamprin, Floxapen and Chloramphenicol. Some of the organisms were resistant and others susceptible to the other antibiotics (Table 4).

Table 1: Prevalence of significant bacteriuria among students of UDSS

\begin{tabular}{|c|c|c|c|c|c|c|c|c|}
\hline & $\begin{array}{l}\text { Number of } \\
\text { subjects with } \\
\text { significant } \\
\text { bacteriuria }\end{array}$ & $\%$ & $\begin{array}{l}\text { Number of subjects } \\
\text { With non signify } \\
\text { cant bacteriuria }\end{array}$ & $\%$ & $\begin{array}{lr}\text { Number } & \text { of } \\
\text { subjects } & \text { with } \\
\text { mixedculture } & \end{array}$ & $\%$ & $\begin{array}{l}\text { Number of } \\
\text { subjects with no } \\
\text { growth }\end{array}$ & $\%$ \\
\hline $\begin{array}{l}\text { Total } \\
\text { number } 100\end{array}$ & 10 & 10 & 59 & 59 & 20 & 20 & 11 & 11 \\
\hline $\begin{array}{l}\text { Total males } \\
50\end{array}$ & 4 & 8 & 31 & 62 & 8 & 16 & 7 & 14 \\
\hline $\begin{array}{l}\text { Total } \\
\text { females } 50\end{array}$ & 6 & 12 & 28 & 56 & 12 & 24 & 4 & 8 \\
\hline
\end{tabular}

Table 2: Frequency of occurrence of Bacterial Isolates

\begin{tabular}{llll}
\hline Bacterial isolate & $\begin{array}{l}\text { Frequency } \\
\text { occurrence }\end{array}$ & $\begin{array}{l}\text { of } \\
\text { population of } 100 \text { samples }\end{array}$ & $\begin{array}{l}\text { Percentage frequency in } \\
\text { sample with } \\
\text { bacteriuria(10) }\end{array}$ \\
\hline Staph. Aureus & 03 & 03 & 30 \\
S. epidermidis & 03 & 03 & 30 \\
E. coli & 02 & 02 & 20 \\
Pseudomonas spp & 01 & 01 & 10 \\
Proteus spp & 01 & 01 & 10 \\
\hline Total & 10 & 10 & 100 \\
\hline
\end{tabular}

Table 3: Antibiotic susceptibility pattern of gram negative isolates

\begin{tabular}{|c|c|c|c|c|c|c|c|c|c|c|c|}
\hline $\begin{array}{l}\mathrm{S} / \mathrm{N} \text { of } \\
\text { isolate }\end{array}$ & $\begin{array}{l}\text { Organism } \\
\text { isolated }\end{array}$ & OFX & NA & PEF & $\mathrm{CN}$ & $\mathrm{AU}$ & $\mathrm{CPX}$ & SXT & CEP & $\mathrm{S}$ & PN \\
\hline 03 & E. coli & $\mathrm{R}$ & $\mathrm{R}$ & $\mathrm{R}$ & $\mathrm{R}$ & $\mathrm{S}$ & $\mathrm{R}$ & $\mathrm{R}$ & $\mathrm{S}$ & $\mathrm{S}$ & $\mathrm{S}$ \\
\hline 025 & E. coli & $\mathrm{R}$ & $\mathrm{R}$ & $\mathrm{R}$ & $\mathrm{R}$ & $\mathrm{S}$ & $\mathrm{R}$ & $\mathrm{S}$ & $\mathrm{S}$ & $\mathrm{S}$ & $\mathrm{S}$ \\
\hline 031 & Pseudomonas spp & $\mathrm{R}$ & M & $\mathrm{R}$ & $\mathrm{R}$ & $\mathrm{S}$ & $\mathrm{R}$ & $\mathrm{R}$ & $\mathrm{S}$ & $\mathrm{R}$ & $\mathrm{S}$ \\
\hline 056 & Proteus Spp & $\mathrm{R}$ & $\mathrm{R}$ & $\mathrm{R}$ & $\mathrm{R}$ & $\mathrm{R}$ & $\mathrm{R}$ & $\mathrm{S}$ & M & $\mathrm{R}$ & $\mathrm{R}$ \\
\hline Key & $\begin{array}{l}\mathrm{S}=\text { Sensitive } / \text { Susce } \\
\mathrm{R}=\text { Resistant } \\
\mathrm{M}=\text { Moderately Sens }\end{array}$ & ble & ibbe & & & & & & & & \\
\hline
\end{tabular}

* Corresponding author: Frank-Peterside, N. 
Table 4: Antibiotic susceptibility pattern of gram positive isolates

\begin{tabular}{|c|c|c|c|c|c|c|c|c|c|c|c|}
\hline $\begin{array}{l}\mathrm{S} / \mathrm{N} \text { of } \\
\text { isolate }\end{array}$ & $\begin{array}{l}\text { Organism } \\
\text { isolated }\end{array}$ & CPX & $E$ & $\mathrm{LC}$ & $\mathrm{CN}$ & APX & $\mathrm{RD}$ & FLX & $\mathrm{S}$ & NB & $\mathrm{CH}$ \\
\hline 04 & S. aureus & $\mathrm{S}$ & $\mathrm{R}$ & $\mathrm{S}$ & $\mathrm{S}$ & $\mathrm{S}$ & $\mathrm{S}$ & $\mathrm{S}$ & $\mathrm{R}$ & $\mathrm{S}$ & $\mathrm{S}$ \\
\hline 016 & S. aureus & $\mathrm{S}$ & M & $\mathrm{S}$ & $\mathrm{S}$ & S & $\mathrm{S}$ & $\mathrm{S}$ & $\mathrm{R}$ & $\mathrm{S}$ & $\mathrm{S}$ \\
\hline 048 & S. epidermidis & $\mathrm{R}$ & $\mathrm{R}$ & $\mathrm{S}$ & $\mathrm{S}$ & $\mathrm{S}$ & $\mathrm{S}$ & $\mathrm{S}$ & $\mathrm{S}$ & $\mathrm{S}$ & $\mathrm{S}$ \\
\hline 067 & S. aureus & $\mathrm{S}$ & $\mathrm{R}$ & $\mathrm{S}$ & $\mathrm{S}$ & $\mathrm{S}$ & $\mathrm{S}$ & $\mathrm{S}$ & $\mathrm{R}$ & $\mathrm{S}$ & $\mathrm{S}$ \\
\hline 081 & S. epidermidis & $\mathrm{R}$ & $\mathrm{R}$ & $\mathrm{S}$ & $\mathrm{S}$ & S & $\mathrm{S}$ & $\mathrm{S}$ & $\mathrm{S}$ & $\mathrm{S}$ & $\mathrm{S}$ \\
\hline 093 & S. epidermidis & $\mathrm{R}$ & $\mathrm{R}$ & $\mathrm{S}$ & $\mathrm{S}$ & $\mathrm{S}$ & $\mathrm{S}$ & $\mathrm{S}$ & $\mathrm{S}$ & $\mathrm{S}$ & $\mathrm{S}$ \\
\hline & $\begin{array}{l}\text { Sensitive / Susc } \\
\text { Resistant } \\
\text { = Moderately Se }\end{array}$ & ble & & & & & & & & & \\
\hline
\end{tabular}

\section{DISCUSSION}

This study was carried out to determine the presence of asymptomatic bacteriuria among 100 otherwise healthy students of UDSS. Prevalence of asymptomatic bacteriuria was observed in $10 \%$ of the population. Olusanya et al, 1993 attributed the high level of asymptomatic significant bacteriuria in their study population to the use of mid-stream urine sample. Others argue that transabdominal bladder aspirate give more reliable results (Lennuette, et al, 1980; Mc Geachie and Kennedy, 1963). This is not however advisable in a screening survey. Another reason for this high incidence may be due to the fact that those studied belonged to the low/middle socioeconomic group. Socio-economic level has been reported to have an effect on prevalence of bacteria in a pregnant population (Turch et al, 1962, Olusanya, et al, 1993).

The females had a higher prevalence (6\%) than the males (4\%).This observation is in agreement with Prescott, 1999 who reported that bacteriuira is more common in females and is often asymptomatic with frequent reoccurrence (Prescott, 1999). Higher prevalence of asymptomatic UTI in females than males has also been observed by other workers (Modarres and Oskoii, 1997, Abbey, 1987, FrankPeterside and Oguike, 2006, Frank-Peterside and Eton, 2007). While $89 \%$ of the population studied showed growth, it will not be ruled out that the mixed bacterial growth obtained could be common contaminants or from careless students. It can also be due to the presence of intestinal bacteria or contaminants from the vagina, faeces or perinial skin especially in females. The bacterial species isolated in this study were five. These species have also been isolated in similar studies by different investigators of UTI (Modarress \& Oskoii, 1997; Abbey, 1987; Olusanya et al, 1993). The most prevalent organism isolated in this study was S. aureus, $60 \%$. Coagulase positive Staphylococci may have invaded the UTI through hematogenous routes while the coagulase negative Staphylococci may invade the urinary tract through sexual activity in females. This study has shown that some bacterial isolates are more susceptible to treatment with certain antibiotics than others. This should be the consideration for the choice of an antibiotic. Three antibiotics, Ciproflox, Gentamycin and Streptomycin were found to be most effective for Gram negative and Gram positive organisms.

If detected, asymptomatic bacteria should be investigated and proper antibiotic treatment administered. Early detection and treatment could avert more serious problems of the urinary tract. There are conflicting views as to the necessity of including screening of secondary school children for asymptomatic bacteriuria. It is our opinion that asymptomatic bacteriuria investigation be included as part of the health requirement for admission in secondary schools as we have discovered that they could be incubating asymptomatic infection and ordinarily would not go to see a doctor.

We acknowledge the technical assistance given to us by Miss. F. Onyiro

\section{REFERENCES}

Abbey, S.D (1987). Asymptomatic bacteriuria in the Port Harcourt metropolis of Nigeria. Microbios 49 (199): 73-7.

Atlas, R.M. (1986). Basic and Practical Microbiology Textbook Macmillan co. NY.

Bailey and Scott (1994). Diagnostic Microbiology $9^{\text {th }}$ edition 1994 Ellen Jo Baro Publishers Musby.

Black, J.G. (1993). Microbiology principles and application second edition Prentice Hall Eaglewood Cliffs NJ. 
Cheesebrough, M. (2000). District laboratory practice in tropical countries (Part 2) Cambridge.

Epoke, J, Odigue, C.O; Anyanwu, G.O.C and Opara, A.A (2000). The prevalence of significant bacteriuria in diabetic patients in Calabar, Nigeria. Diabetes International 10(1): 16-17.

Frank-Peterside and Eton, E (2007).Asymptomatic bacteriuria among pupils of the University of Port-Harcourt Demonstration Primary School, Rivers-State, Nigeria. Asian Journal of Microbiol. Biotech. and Env. Sci. Vol 9 No.3:543-546.

Frank-Peterside, N and Oguike, N (2006).Asymptomatic significant bacteriuria among students of the University of PortHarcourt. Nigeria. Nig. J. of microbiology 20(3):1252-1257.

Gill, G. V. (1990) Modern Drug Therapy: Antibiotics Med Digest 10:13-21.

Guyton and Hall (2000) Medical physiology. 10 Edition W. B. Saunders.

Hugo, W.B and Russell, A.D. (1992) Pharmaceutical Microbiology $5^{\text {th }}$ Edition Blackwell Publishing co.

Lennuette, E. H; Balow, S. A; Hausler W.Jr and Truant, J. O. (1980). Manual of Clinical Microbiology ( $3^{\text {rd }}$ edition) American Society for Microiology Publications. Washington, U.S.A.

McGeachie ,J and Kennedy A. C.(1963). Simplified quantitative method for bacteriuria and pyuria. J Clin. Pathol 16: 32-38.

Modarres, A and Oskoii, N. (1997). Bacterial etiologic agents of urinary tract infection in children in the Islamic Republic of Iran. Vol 3, Issue 2: 290 - 295.
Nester, Roberts, Pearsall and Anderson Nester (1998). Microbiology textbook, A human perspective. $2^{\text {nd }}$ Edition WCB Mc Graw Hill pg 599-604.

Ojiegbe, G.C and Nworie, W. C. (2000). Asymptomatic bacteriuria among school pupils in Enugu Area, Enugu, Nigeria. J. Med. Lab.Sci. 9(1):42-46.

Olusanya, O. (1984). Factors affecting the prevalence of significant bacteriuria among school children in Ile-Ife; Nigeria N. J. Microbiology 4(1-2): 6671.

Olusanya , O; Oguniedun, A and Fakoya, T.A. (1993). Asymptomatic significant bacteriuria among pregnant and non-pregnant women in sagamu, Nigeria. West African Journal of med vol.12: No 1: 27-34

Prescott, M; Harley, P and Klein, A. (1999). Microbiology, $4^{\text {th }}$ edition. Mc Graw-Hill Book Co. New York.

Siegel, S.R; Siegel, B, Sokoloff, B. Sokoloff, B.Z and Kenter, M. H (1980). Urinary infection in infants and pre school children. AVDC: 134: 369 - 372

Smith, M.B.H (1994). Screening for urinary tract infection in asymptomatic infants and children.Canadian Guide to Clinical Preventive Health Care: 220 - 30

Stamm, W.E and Hooton, T.M (1993). Management of UTIs in adults. N. Eng. Med: 239: 1328 1334.

Touch, M, Goffe, B.S and Peterdorf R. G. (1962). Bacteriuria in Pregnancy (relationship to socioeconomic factors) N.Eng. J. Med. 266; 857 $-866$. 